\title{
Ethnic Memory And Historical Injustices In Nigeria
}

\author{
Atere Clement Olusegun \\ Department of Languages \& Translation \\ Taibah University, Kingdom of Saudi Arabia
}

\begin{abstract}
It is a known fact that not few Nigerians believed that the country has committed atrocities against her citizen and this has caused mutual suspicion, deep divisions, inter-ethnic wrangling, and unending disputations in this ethnically and geographically diverse nation. The aim of this paper is to provide fresh insight on the causality of the deep mistrust and mutual suspicion among the various ethnic groups which in turn has caused the Nigeria nation much needed unity. The paper argued that recurring memorialization of unresolved historical injustices has been a potent poison to the glowing of communal and organic wellbeing of the nation. The paper concluded that the government must redress the past historical injustices, explore how Nigerians together can search for common memories to meet present needs, and allow the various ethnic group to come to terms with their past. The paper recommended new Truth and Reconciliation Commission
\end{abstract}

Keywords: Ethnicity, Ethnic Memory, Ethnocentrism and Historical Injustices

\section{INTRODUCTION}

The creation of the entity called Nigeria was completed in 1914. The unification of the Northern and Southern part bring into completion the unification policy of British imperial rule. This unequally yoked marriage of inconvenience amalgamation called Nigeria has inflicted unmitigated injury on many inhabitants. Nigeria has committed atrocities against her citizen, and this has caused mutual suspicion, deep divisions and inter-ethnic wrangling.

In our recent past history, acts that traumatize the moral conscious of men are somewhat common. Our situation is not different from that which was described by Janna Thompson (2001) when describing the evil of slavery in African; History," as has it, "is a tale of unrequited injustice. Treaties have been broken, communities wiped out, cultures plundered or destroyed, innocent people betrayed, slaughtered, enslaved, robbed, and exploited.

All the above had happened in Nigeria and there had been no apology to the victims. Nigeria been a nation wracked by tension and mutual hostilities has the history that has inflicted considerable emotional harm along ethnic divides and this is evident daily in our social and political life. And we must begin to ask ourselves in Nigeria today as did Martin Luther King, Jr (1967). How long will prejudice blind the visions of men, darken their understanding, and drive bright-eyed wisdom from her sacred throne... when will wounded justice, lying prostrate on the street of Selma and 
Olusegun, A. C. (2020) Ethnic Memory And Historical Injustices In Nigeria. Advances in Social Sciences Research Journal, 7(5) 545-555.

Birmingham and communities all over the South, be lifted from this dust of shame to reign supreme among the children of men?

When the Nigeria truth commission, the Oputa Panel, was set up in 1999 to investigate and recommend the appropriate redress of human rights violations committed between 1966 and 1999; not few Nigerians were happy thinking that truth will be revealed and that apologies will be rendered. Many thought that wounded and agitated hearts across the ethnic divides will be calmed and that all these will lead to the end of many evils of tribalism in Nigeria. Unfortunately the golden opportunity to explore how Nigerians together can search for common memories to meet present needs was lost when the Commission's findings were annulled by the government, and consequently refused to implement any of its recommendations.

For how long will the injustices of the past lie prostrate on the streets of Nigeria, when will the terrible sickness of mutual suspicion in Nigeria be cured? Where will the boldness to speak the truth concerning our past come from?

\section{Ethnicity}

\section{CONCEPTUAL CLARIFICATIONS}

The concept of ethnicity has been variously defined by scholars; Cohen (1974) for instance avers that an ethnic group is a collection of people who share some patterns of normative behaviour and form a part of a larger population, interacting with people from other ethnic groups within the framework of a social system. Regmi (1995) described the phenomenon of ethnicity as:

The expressive aspect of ethnic identities: it involves consolidation, mobilisation, goal setting and goal attainment... It is part sentiment, part ideology, and part agenda (p. 5).

Nnoli $(1978$, p.5) sees ethnicity as a: Social phenomenon associated with the identity of members of the largest possible competing communal groups (ethnic groups) seeking to protect and advance their interest in a political system.

Nigeria is rich in cultural diversity represented through 200 to 250 ethnic groups (Emelonye , 2011 p.15), each of which is competing for relevance and with terrible anxiety of being dominated by other and each complaining of political marginalization. Various sections of Nigeria have used ethnicity as a vehicle to get a fair share of the national cake, and the inability of Nigerian society to unite, caused in part by its postcolonial history, is a source of the worsening economic and social tragedy facing Nigeria over the last half a century (Adebanwi \& Obadare, 2010, p.386).

In The federal republic of Nigeria with more than 250 ethnic groups, according to Atere (2019) there is constant complaining of domination of the minorities by the major group, the Hausa, the Igbo, and the Yoruba ethnic groups. The domination accusation is not farfetched because these 3 groups have greater numbers in population, and this makes their involvement in successive government dominant since independence. It is no gainsaying therefore, to affirm that Nigeria has an ethnicity problem. It is obvious from the many high-profile and violent cases of ethnic clashes across the country. The pervasive ethnic stereotyping and myth-making that goes on between ordinary civilians has the capacity to destroy the very fabric of Nigerian society (Soyemi 2016). Putnam (1993) in his thesis on national cohesion posited that trust is at the very center of any successfully 
functioning society. In Nigeria, unfortunately, this trust is missing among the various ethnic groups and this had and continue to hamper nation-building. The mutual distrust and up scaled ethnophobia again played out in the reaction of Nigerians to the death of Mallam Abba Kyari. A HausaFulani by birth was the Chief of Staff to President Mohammed Buhari from September 2015 till April 172020 when he died of COVID 19 which he contracted in the line of duty. Odeshola (2020) wrote in the Punch newspaper view point thus; "Haba! Since the bell tolled for Kyari, the land is not soaked in tears...In countless communities across the land, fists punch the air, flutes on songs. Online and offline, many laugh and rejoice, happy that a calamity has befallen the Aso Rock" The question is why would some people be happy for the death of a man who, according to the testimonies of many that knew him well and those that worked with him, was a good man. According to President Buhari (2020) in political life, Abba never sought elective office for himself. Rather, he set himself against the view and conduct of two generations of Nigeria's political establishment - who saw corruption as an entitlement and its practice a byproduct of possessing political office. However, blinded by the deep distrust along the ethnic lines, no good thing can come from a Hausa- Fulani.

\section{Ethnic Memory}

Ethnic memory is an act of constant collective remembrance of histories of recognized injustice and atrocity that had been committed against an ethnic group by the nation which they are part and to the extent such memory so conceived haunts such ethnic group and determines their reactions to their nation. Thelen (1989) discussing the historical study of memory posit that it would be;

The study of how families, larger gatherings of people, and formal organizations selected and interpreted identifying memories to serve changing needs. It would explore how people together searched for common memories to meet present needs, how they first recognized such a memory and then agreed, disagreed, or negotiated over its meaning, and finally how they preserved and absorbed that meaning into their ongoing concerns. (p.1118)

According to Barklis (2016) Memory makes the past present, and thus makes it possible for the past to be addressed in the present. Memory therefore has a special place among past-regarding practices, because it is a precondition for any further past-regarding action.

Chinese still remember the period from roughly 1849 to 1949 as the "century of humiliation." It was a turbulent time ...Chinese people were dominated by the Japanese, French and English. Although the century was declared over in 1949 when the People's Republic of China was established, the Chinese remember the sting of those times and still interpret modern events through them. ( Roediger III and DeSoto 2016).

Nigerian people will never forget the period (1966-1979) and (1983-1999) when the nation witnessed an authoritarian form of government led by committee of military leaders with little or no consideration for public opinion. It was a period of military brutality, abuse of power and war crimes were committed by both the Nigerian Army and Police. In Nigeria today, the fear of Hausa Fulani or in the word of Obasanjo, Fulanization is the beginning of wisdom among other various ethnic groups and this is borne out of their past experiences. Tribal idiosyncrasies has ultimately lead to contemptuousness, disharmony, and genocidal reprisals in the country to the extent that it may be argued that the nation is putting herself up for a combustion that may terminate the nation as it is now. 


\section{Ethnocentrism}

It will be difficult to adequately address the issues of ethnic memory in Nigeria without discussing the ethnocentrism in the country. According to (Hofmann \& Kovalev 1989) ethnocentrism is believed by scholars to have been created by Austrian sociologist Ludwig Gumplowicz who defined it as a "the reasons by virtue of which each group of people believed it had always occupied the highest point, not only among contemporaneous peoples and nations, but also in relation to all peoples of the historical past". Though it is present in little forms in every culture, history has shown us how it can have tragic consequences if not controlled. Ethnocentrism is an evil menace in multiethnic Nigeria has a great distrust among different ethnic groups. According to (Aluko \& Usman 2016). Hausa man may think a Yoruba man is inferior, while the Yoruba man in turn communizes the Igbo; and Igbo man concedes to himself that both the Hausa and Yoruba are just the people without gut. The root cause of ethnocentric politics in Nigeria can be traced to the mutual suspicion that existed even before the amalgamation of geographical divisions to form the country called Nigeria. This distrust which has existed for almost a century has been exploited time and again by politicians... Given our current circumstances, it goes without saying that a solution is urgently required in order for the nation to move forward (Eniola 2013)

The Hausa-Fulanis dominates the Northern part of the country and they consider themselves as born leaders and owners of Nigeria. Alhaji Ahmadu Bello was reported to have portrayed the Nigerian Nation as a personal property belonging to his ethnic group and his Islamic faith thus;

"The new nation called Nigeria should be an estate of our great Grandfather Othman Danfodio. We must ruthlessly prevent a change of power. We use the minorities in the North as willing tools and South as conquered territory and never allow them to rule over us and never allow them to have control over our future" (Shilgba, 2011).

Also according to Kukah, (2003:98) Alhaji Shehu Malami, a Sokoto Prince, and Alhaji Maitama Sule, to the bewilderment southerners, were informed that they (Hausas/Fulanis) acquired their dark skin from inter-marriages with the local Africans and that they were endowed with leadership qualities.

The South-West dominated by the Yorubas believe they are the most educated thus qualified to rule the Nigerian Nation, they see the Hausa-Fulani as backward and uneducated, and see the Igbos as arrogant, selfish, and a traitor. The East, predominantly Igbos, felt superior in terms of thinking and industry, thus they believe the business of developing Nigeria, especially as relates commerce and industrialization is better placed in their hands. Even the people of the South- South Nigeria, a minority group believe that they are the source of Nigeria fortune, the one proverbial hen that lays the golden eggs of crude in Nigeria.

\section{RECOGNIZED HISTORICAL INJUSTICE IN NIGERIA}

Historical injustice is the past moral wrong committed by previously living people that has a lasting impact on the well-being of currently living people (Meyer 2015). Understanding the history will give way to amending the ugly past and if possible persuade the present government to take responsibility for the past and cure the injustices that endure in their midst and the burden of victimhood will be lessened 
We cannot discussed the issue of historical injustices meaningfully without discussing transitional justice, when something is wrong, there is the need to put it right. Transitional justice is predominantly constructed around human rights violations. In a nutshell, transitional justice involves delineating narration of violations and finding the remedy (Nagy, 2008). According to Teitel (2002) Transitional justice focus on the most effective and appropriate ways of addressing past wrongs and establishment of a decent society.

There is also "Social Justice" which according to Zajda, et.al (2006) which generally refers to the idea of creating a society or institution that is based on the principles of equality and solidarity, that understands and values human rights, and that recognizes the dignity of every human being.

Successive military regimes and civilian administrations perpetrated abuses and listed below are some of the specific historical injustices;

\section{January 15, 1966 Coup and counter coup}

The first Coup by a group of young, idealistic, UK-trained army majors, mainly of Igbo origin overthrew Nigeria's democratic government in a violent military coup. According to Siollun (2009). The officers who staged the coup were mostly Christian southerners from the Igbo ethnic group, and they assassinated several northerners, including the four highest-ranking northern army officers, Prime Minister Tafawa Balewa, and Northern Region Premier Ahmadu Bello (both Muslims from the north). Although coup leaders described it as revolution to end corruption and ethnic rivalry in Nigeria, majority in the Northerner region strongly believe that it was an Igbo plot to wrest power from the North and dominate the Country.

\section{July 28, 1966 Counter Coup}

It is not a surprise to all close watchers of ethnic issues in Nigeria to see the staging of the counter coup. It was a reaction to the killings of Northern politicians and Army Officers by mostly Igbo soldiers on January 15, 1966. On July 29, 1966, northern Nigerian troops led a counter-coup against the Igbo-dominated junta in the former capital Lagos (Matthaei 2016). The coup resulted in the murder of Nigeria's first military Head of State General Johnson Aguiyi-Ironsi and Lt Colonel Adekunle Fajuyi (who was hosting a visiting Aguiyi-Ironsi in Ibadan). In the words of Omoigui (2002)

By this time, Lt. Pam Nwadkon's Ferret group had arrived from Abeokuta bringing more inciting news about how Igbo soldiers there had been hunted down and killed. At this meeting surviving Igbo soldiers were allegedly rounded up by NCOs and later killed, some say by being packed like sardines into a tailor's shop and then blown up with grenades.

\section{Igbo Massacre in the North}

The people of the Eastern Nigeria will not also forget the killings of their kinsmen in the Northern region immediately after the coup and counter coup of 1966. Obasi (2017) claimed that Igbo have suffered great losses. Mostly notably, over 30,000 Igbo in the north were killed and two million fled back to the south in 1966 in the "Igbo pogrom" that followed the January coup and July countercoup. Unfortunately 46 years after, a distinguished Igbo, Chinua Achebe, C (2012) claimed that "Nigerians of all other ethnic groups will probably achieve consensus on no other matter than their 
Olusegun, A. C. (2020) Ethnic Memory And Historical Injustices In Nigeria. Advances in Social Sciences Research Journal, 7(5) 545-555.

common resentment of the Igbo. They would all describe them as aggressive, arrogant and clannish. Most would add grasping and greedy"

\section{The Nigeria Civil War (Biafra War) 1967-70}

Nigerian Civil War (1967-1970) was due to intense disagreement between some of the major ethnic groups with the Nigeria component nation (Erhagbe, 2002; Ekeh, 1972). Central to Nigeria's historical memory today, is the Nigeria-Biafra War, especially, the pogroms committed against the Igbo by the Nigerian State. It is from that historical reality and experience we must learn (Oborji 2019).

Interestingly and unfortunately, the way the war was prosecuted by the Nigeria government had been severely criticized as not been free from war crimes. (Goetz, 2001) describing the wartime policy claimed that the policy ensured that foreign aid, particularly food donations, was prevented from reaching Biafra. With deliberate denial of food to Biafra, the area was then confronted by food shortages, hunger, malnutrition, disease and death of millions of people, especially children.

Benjamin Adekunle, one of the military war commanders said at a press conference attended by journalists including those from the international media in August 1968 press conference said,: 'We shoot at everything that moves, and when our forces march into the center of I[g]bo territory, we shoot at everything, even at things that do not move'. (Ekwe-Ekwe, 2011)

\section{The Annulment of the June 12, 1993 Presidential Election}

It is not yet clear how the Yorubas will forgive and forget the annulment of the election of a promising Yoruba man, M K O Abiola, for them it was an immeasurable injustice to the Yoruba nation. The National Defence and Security Council of Nigeria headed by General Ibrahim Badamosi Babangida annulled the results of the June 12 elections on June 23, 1993 in a most bizarre manner; nullifies all the relevant court decisions, suspends NEC through an unsigned terse statement. (Toromade 2017) writing on the speech annulling the election quoted the president as saying thus;

"To continue action on the basis of the June 12, 1993 election, and to proclaim and swear in a president who encouraged a campaign of divide and rule among our ethnic groups would have been detrimental to the survival of the Third Republic".

The agitations that followed the annulment of the election led to more human right abuses.

\section{The 'Judicial Murder' Ken Saro-Wiwa \& 8 0thers}

The problem started when MOSOP (Movement for the Survival of the Ogoni People) led by Ken SaroWiwa developed Ogoni Bill of Rights. The bill called for increased autonomy for the Ogoni people, a fair share of the proceeds of oil extraction and rehabilitation of the damage done to Ogoni land. The Ogoni took up the peaceful fight against Shell and the military regime of Nigeria. In 1993, Shell abandoned Ogoni land and has not been back since. General Sani Abacha had the writer arrested in 1994, allegedly for being responsible for the death of four Ogoni tribal leaders. Saro-Wiwa was hanged on November 10, 1995.(Kriesch, 2015). According to (War on Want (2015) the repression of the Ogoni did not end with the death of the Ogoni Nine. Following their execution the Nigerian government established the Rivers State Internal Security Task Force comprising the police, and armed forces to root out dissent in the region. Many of those arrested were never seen again. 


\section{Odi Massacre}

Odi massacre was an attack carried out on November 20, 1999, by the Nigerian military on the predominantly Ijaw town of Odi in Bayelsa State. According to Nigeria - Human Rights Watch World Report (2000). On November 4, 1999, an armed gang killed seven Nigerian policemen in the community of Odi, Bayelsa State, in the oil producing Niger Delta region in the far south east of the country. Five other police were killed in subsequent days. The president, Olusegun Obasanjo deployed soldiers to the town on November 20, 1999 after the alleged failure of Bayelsa state government to produce the armed gang. According to Omon-Julius (2002) Two thousand four hundred and eighty three persons lost their lives during the military invasion of Odi, an oil producing community in the Niger-Delta State of Bayelsa, the Environmental Rights Agenda (ERA) has alleged.

\section{Zaki Biam Massacre}

According to Obi-Ani (2008) In 2001 Determents of soldiers were drafted to the area, and yet the crises continued to escalate. Accusations were made that the soldiers were taking sides in the conflict, with fingers pointed at the then Defence Minister, General Danjima, who hails from Jukun, as aiding and abetting this sordid act. In October 2001, the Tiv militias in Zaki Biam murdered nineteen (19) soldiers on peace keeping in the area. However, the reprisal began on Monday, October 22, when soldiers from the 23rd Armoured Brigade of the 3rd Armoured Division of the Nigeria army rounded up residents in Gbeji village for a "meeting' 'According to reports, they were made to sit on the ground and the military separated the men from the others. Afterwards, the soldiers opened fire on the men indiscriminately. Witnesses reported that some of the victims' bodies were then set ablaze. (Blueprint.ng, 2018).

There are many other injustices in Nigeria; the murder of the Newswatch by letter bomb in 1986. The assassination of Kudirat Abiola in 1996 and several high profile assassinations of government critics like Rear Admiral Babatunde Elegbede (Rtd), Admiral Olu Omotehinwa, Chief Alfred Rewane, Mrs. Bisoye Tejuosho, Alhaja Suliat Adedeji, Dr. Shola Omosola to mention just a few. These social injustices are obvious to the common man on the street and has led to a large spectrum of our population to lose faith in Nigeria, if not properly addressed, Nigeria could soon become a failed state (Esan, 2012).

\section{CONCLUSION AND RECOMMENDATION}

The way we view history determines the way we perceive the present and this in turn dictates what answers we provide for existing problems. Across the globe, we can identify some significant dates that have shaped and still continue to shape human and societal relations. (Ojukwu \& Oni, $2016 \mathrm{p}$. 12). The African God, surely according to (Hayford, 1930) is weary of our wrangling, weary of our vain disputations, weary of our everlasting quarrels which are a drag upon progress and which keep from us as a people, the good that is intended for us

The problem of addressing and possibly compensating for injustices from the past has elbowed itself onto the world stage during the past decade. Inspired by the successes of the Holocaust claimants, every manner of group in most corners of the world is pressing claims for dealing with unfair treatment in the past (Gibson, 2004). The Nigeria nation cannot be an exception, we must make amend for the past. There is a clear need for justice and it is best served when it is not delayed because justice delayed is justice denied. The best way to transit into a decent society in Nigeria is 
Olusegun, A. C. (2020) Ethnic Memory And Historical Injustices In Nigeria. Advances in Social Sciences Research Journal, 7(5) 545-555.

for the various ethnic group to come to terms with their past. It is very important for a day of reckoning to come where there will be investigation of various human right abuses, and atrocities committed against one another in the past.

Opportunity to recognize ethnic memory and then agree or disagree, or negotiate over their various meaning, preserved and absorbed that meaning into national question was lost when the Justice Oputa Truth Commission findings was dumped and become of no effect.

After the end of the civil war in 1970 successive governments in Nigeria have continued to search for peaceful coexistence of the various ethnic groups in Nigeria. Unfortunately all the efforts to reconcile and integrate various ethnic groups in Nigeria have failed so far. The Federal Character Commission was established by Decree No. 34 of 1996. However the distinctive desire of Nigerians to ensure and promote national loyalty, unity and national harmony and to give the people of Nigeria sense of belonging according to (Aderonke, 2013) have not been realized. The federal Character policy has failed to promote national unity and the command of national loyalty.

I hereby recommend that the government establish a new Truth and Reconciliation Commission with emphasis on non- retaliatory approach and based on reconciliatory principle.

"...historical understanding is not only a mirror on the past but also .... g guide to the future. [W] must be prepared to confront this history, if we are to forge ahead. We need to understand it, even if it means asking unpleasant questions and offering blunt answers" (HRVIC 2002: 87).

A truth and reconciliatory commission, if it successfully pursue, will create an agreed account of our ugly past in such a way the past will no longer interferes with our future. The perpetrators of the human right abuses will acknowledge that crimes were perpetrated against their victims and ask for forgiveness and forgiveness shall be granted to perpetrators by the victims.

As it is now, most Nigerians emotionally ranked their identities first as Yoruba or Igbo, or Hausa, or Fulani before seeing themselves as Nigerian. Until Nigerians see themselves first and foremost politically as citizens of the Nigeria before their ethnic affiliation there cannot be real unity. Citizens should be taught to cut off from weak and divisive foundations, de-emphasize the cosmetic divisions that is filled with antagonistic ethnic groups and embrace nationalism and patriotism for our country to be united.

\section{References}

Adebanwi, W. \& Obadare, E. (2010). Introducing Nigeria at 50: The Nation in Narration. Journal of Contemporary African Studies, Vol 28, October 5, 2010-Issue 4: 379 - 405.

Aderonke, M. (2013) Federal Character Principle as a Recipe for National Integration in Nigeria: An Overview International Journal of Advanced Research in Management and Social Science 2 (6) 65-84

Aluko, O. I \& Usman, S (2016) Visiting the Hippopotamus: National Integration Issues In Nigeria. The Journal of Romanian Science Association. Vol 10, No 1 retrieved April 17, 2020 from http://www.rrsa.ro/rjrs/V1014.Idowu.pdf

Atere, C O. (2019) The Ethnic Dimension to Corruption in Nigeria's Public Sector (1999-2018) Unpublished Thesis Submitted in the Department Of Political Science And Public Administration Veronica Adeleke School Of Social Sciences In Partial Fulfilment Of The Requirements For The Award Of The Degree Of Doctor Of Philosophy Babcock University Ilishan-Remo Ogun State Nigeria 
Buhari, M. (2020) Abba Kyari, a friend I knew for 42 years

Premium Times of 18 April 2020. Retrieved April 20, 2020 from https://www.premiumtimesng.com/news/topnews/388665-abba-kyari-a-friend-i-knew-for-42-years-buhari.html

Esan, A. (2012). "Absence Social Justice, Cause of Insecurity- Fasehun" March 4, 20 12: Accessed April 28, 2020 at www.nationalmirroronline.netlpolitics/32969.html.

Omoigui, N. (2002) OPERATION 'AURE': Northern Nigerian Military Counter-RebellionJuly, 1966 http://www.waado.org/NigerDelta/Nigeria_Facts/MilitaryRule/Omoigui/NorthCounterCoup.htm

Matthaei, K. (2016). Coup, counter-coup and the Biafran War. Retrieved April 22, 2020 from

https://www.dw.com/en/coup-counter-coup-and-the-biafran-war/a-19437061

Siollun, M. (2009) Oil, Politics and Violence: Nigeria's Military Coup Culture (1966-1976). Algora. pp. 98-102. ISBN 9780875867090 .

Emelonye, U. (2011). Nigeria: Peace Building through Integration and Citizenship. Published by International Development Law Organization Viale Vaticano, 10600165 Rome, Italy

Ekwe-Ekwe, H. (2011). The most tragic day of Igbo history: 29 May 1966. Retrieved April 22, 2020 from https://www.pambazuka.org/governance/most-tragic-day-igbo-history-29-may-1966

Eniola, B (2013) Repositioning Nigeria: Adoption Of 'Politics Of Issues. Retrieved April 17, 2020 from 'https://risenetworks.org/repositioning-nigeria-adoption-of-politics-of-issues/

Goetz, N H.(2001) Humanitarian Issues in the Biafra Conflict, Geneva: UNHCR, 2001pp.4-24(UNHCR working paper; No. 36).

HRVIC. (2002). Human Rights Violations Investigations Commission. Nigeria

Nigeria - Human Rights Watch World Report (2000)The Destruction of Odi and Rape in Choba December 22, 1999.

Retrieved April 26, 2020 from https://www.hrw.org/legacy/press/1999/dec/nibg1299.htm

Janna Thompson, (2001) Historical Injustice and Reparation: Justifying Claims of Descendants Ethics Vol. 112, No. 1 (October 2001), pp. 114-135 Published by: The University of Chicago Press DOI: 10.1086/339139

https://www.jstor.org/stable/10.1086/339139

Martin Luther King, Jr (1967) Beyond Vietnam in A Call to Conscience; The Landmark Speeches of Dr. Martin Luther King, Jr. Edited by Clayborne Carson \& Kris Shepard. Published by Little, Brown and Company

Omon-Julius, O. (2002) Nigeria: 2,483 Died in Odi Massacre, Says Era. This Day Newspaper of November 21, 2002. Sourced April 26, 2020 from https://allafrica.com/stories/200211210232.html

Nagy, R. (2008). Transitional Justice as Global Project: Critical Reflections. Third World Quarterly, 29(2), 275-289.

Odeshola, T. (2020). The Reign of Abba Kyari. The Punch Newspaper of April 20, 2020 p.22

Ojukwu, C \& Oni, E O (2016) June 12 Saga and the Re-Visitation of Igbo-Yoruba

Cold War in Nigeria. Ubuntu: Journal of Conflict and Social Transformation Volume 5, (Numbers 2 \& 3)

June/September, 2016. P 1

Teitel, R. G. (2002). Theoretical and International Framework: Transitional Justice in New Era. Fordham International Law Journal, 26(4), 893.

Soyemi, E A. (2016) Failures of a weak state are to blame for Nigeria's ethnicity problem. Published in the Conversation Journal, sourced on 13, April 2020 from https://theconversation.com/failures-of-a-weak-state-are-toblame-for-nigerias-ethnicity-problem-64186

Paden, J N.(1986) Ahmadu Bello. Sardauna of Sokoto: Values and Leadership Nigeria. London: Hodder and Stoughton, 1986.

Putnam, R. D. (1993) Making Democracy Work: Civic Traditions in Modern Italy (Princeton: Princeton University Press, 1993). 
Olusegun, A. C. (2020) Ethnic Memory And Historical Injustices In Nigeria. Advances in Social Sciences Research Journal, 7(5) 545-555.

Thelen, D. (1989). Memory and American History. The Journal of American History, 75(4), 1117-1129. doi: $10.2307 / 1908632$

Barklis, R. L. (2016) Together in Time: Historical Injustice, Collective Memory, and the Boundaries of Membership. A DISSERTATION Presented to the Department of Political Science and the Graduate School of the University of Oregon in partial fulfillment of the requirements for the degree of Doctor of Philosophy June 2016. Sourced April 14, 2020 fromhttps://scholarsbank.uoregon.edu/xmlui/bitstream/handle/1794/20453/Barklis_oregon_0171A_11535.pdf?se quence $=1 \&$ isAllowed $=\mathrm{y}$

Blueprint.ng, (2018) Benue massacre: Echoes of Zaki Biam. Retrieved April 28, 2020 fromhttps://blueprint.ng/benuemassacre-echoes-zaki-biam/

Roediger, H L. III, DeSoto, K. A (2016). The Power of Collective Memory; what do large groups of people rememberand forget? Springer Nature America, Inc. (Scientific American) is located at 1 New York Plaza New York, NY 10004. https://www.scientificamerican.com/article/the-power-of-collective-memory/

Ekeh, P.P. (1972) "Citizenship and Political Conflict: A Sociological Interpretation of the Nigerian Crisis." in Okpaku J. (ed) Nigeria: Dilemma of Nationhood, (Westport: C.T. Greenwood Press, 1972).

Erhagbe, E.O.(2002)"The Dynamics of the Evolution of Nigeria as a Political Unit." In Nzemeke A.D. \& Erhagbe E.0. (2002) Nigerian Peoples and Culture (Benin City, Mindex Publishing Coy Ltd)

Christian, P J (2012) History, Memory \& Conflict: the collective memory of Maurice Halbwachs Ft Lauderdale, Paper Presentation Stable URL Sourced April 14, 2020 from

file://C:/Users/ATERE/Downloads/History_Memory_and_Conflict_the_collecti\%20(1).pdf

Alexander Hofman, A and Kovalev, A. (1989). Naturalism in Sociology of the Turn of the Century. In A History of Classical Sociology. Ed. by Igor Kon. Moscow, 1989, p. 84. ISBN 5-01-001102-6

Gibson, James (2004). Addressing Historical Injustice Politics and the Past: On Repairing Historical Injustices. Taking Responsibility for the Past: Reparation and Historical Justice. By John Torpey. Rowman \& Littlefield Publishers, Inc., Lanham, Maryland, 2003.

Shilgba,L.K(2011). Towards true Federation: Parrot Newspaper, 12th Oct, 1960: ww.nairaland.com/674760/towardstrue-federation-middle-belt.

Meyer, L H. (2015). The Lasting Impact Of Historical Injustices. Retrieved April 19, 2020 from https://www.britannica.com/topic/historical-injustice

Kriesch, A. (2015). Why Nigerian activist Ken Saro-Wiwa was executed. Retrieved April 26, 2020 from https://www.dw.com/en/why-nigerian-activist-ken-saro-wiwa-was-executed/a-18837442

Kukah, M.H (2003). Democracy and civil society in Nigeria. Ibadan, Spectrum books limited

Nnoli, 0 (1978) Ethnic Politics in Nigeria. (reversed edition 2008). Enugu Fourth Dimension Publishes.

Cohen, A. (1974). The lesson of ethnicity. In A. Mayor (Ed.), Urban ethnicity, ASA Monographs 12. London: Tavistock Publication.

Regmi, R (1995). Ethnicity and Identity. Paper Presented in the National Seminar, Kathmandu: HMGl Nepal, Ministry of Local Government, p.5. Access May 22, 2018 at https://int.search.myway.com/search/GGmain.jhtml

Achebe, C. (2012). The Genocidal Biafran War Still Hunts Nigeria, The Leader (Sunday October 14 - 21), Owerri:

Assumpta Press, p7

Obasi, N. (2017) Nigeria: How to solve a problem like Biafra. Retrieved April 22, 2020 from

https://africanarguments.org/2017/05/29/nigeria-how-to-solve-a-problem-like-biafra/

Obi-Ani, P. (2008) Democratic "Dictatorship" in Nigeria: A Case Study of Odi and Zaki Biam Massacres. Faculty of Arts Journal Vol. 5 P. 152. Retrieved April 28, 2020 from

https://www.researchgate.net/publication/288002922_Democratic_Dictatorship_in_Nigeria_A_Case_Study_of_Odi_an d_Zaki_Biam_Massacre 
War on Want (2015) 20 Years and Still No Justice: We Remember the Ogoni Nine. War on Wants44-48 Shepherdess Walk, London N1 7JP. Retrieved April 26, 2020 from https://waronwant.org/media/20-years-and-still-no-justice-weremember-ogoni-nine

Toromade, S. (2017). Babangida's annulment speech that denied MKO Abiola the Nigerian presidency Sourced April 26, 2020 from https://www.pulse.ng/news/local/june-12-babangidas-annulment-speech-that-denied-mko-abiolathe-nigerian-presidency/cwk7rzh 